\title{
KONSUMTIVISME DAN STATUS SOSIAL EKONOMI MASYARAKAT
}

\author{
Nila Sastrawati \\ Universitas Islam Negeri Alauddin Makassar \\ nila.sastrawati@uin-alauddin.ac.id
}

\begin{abstract}
The needs and desires to become entities, are very difficult to distinguish when examining the current economic actions of society. The community economic growth is increase, both in terms of the availability of resources (means of exchange), the availability of commodities, communication and information technology, the ease of online-based economic transactions, were being supporting factors of the economy and the needs of community. This reality presents a new social phenomenon where an increase in purchasing power is no longer oriented to value of use of an item or service, but has shifted to the symbolic meaning of the goods and services. This was observed by a French philosopher, Jean Baudrillard by analyzing a society that experienced a shift in the concept of consumption from use value to sign value. The control of consumption is significantly able to influence the rational actions of use value toward consumptive actions for other communities, and encourage the creation of socioeconomic status through the conception of a lifestyle of ownership of goods and services.
\end{abstract}

Keywords: Consumivism, Economy, Status, Society.

\begin{abstract}
Abstrak
Kebutuhan dan keinginan menjadi entitas yang sangat sulit dibedakan ketika mengkaji tindakan ekonomi masyarakat saat ini. Pertumbuhan ekonomi masyarakat yang semakin meningkat baik dari aspek ketersediaan sumber daya (alat tukar), ketersediaan komoditi, teknologi komunikasi dan informasi, kemudahan dalam transaksi ekonomi berbasis online, menjadi faktor pendukung bergulirnya roda perekonomian dan pemenuhan kebutuhan dalam masyarakat. Realitas ini menghadirkan fenomena sosial baru dimana terjadi peningkatan daya beli yang bukan lagi berorientasi pada nilai guna suatu barang atau jasa, tetapi telah bergeser pada makna simbolik dari barang dan jasa tersebut. Hal tersebut diamati seorang filsuf Prancis, Jean Baudrillard dengan menganalisis masyarakat yang mengalami pergeseran konsep konsumsi dari nilai guna menjadi nilai tanda. Penguasaan konsumsi secara signifikan mampu mempengaruhi tindakan rasional bernilai guna kearah tindakan konsumtif bagi masyarakat lainnya, dan mendorong terciptanya status sosial ekonomi melalui konsepsi gaya hidup atas kepemilikan barang dan jasa.
\end{abstract}

Kata Kunci : Ekonomi, Konsumtivisme, Masyarakat, Status. 


\section{PENDAHULUAN}

Tindakan konsumtif merupakan realitas pola konsumsi baru yang dikenal dalam paradigma postmodernisme sebagai tindakan yang memaknai barang atau jasa bukan pada nilai guna, tapi bergeser menjadi makna simbolik atau nilai tanda. Hal yang mudah dicermati pada pemilikan barang dengan nilai tinggi yang pada dasarnya bukan merupakan kebutuhan primer. Misalnya, aspek fungsional dari handphone bukan lagi sekedar sebagai sarana komunikasi tetapi menjadi bagian dari gaya hidup, fashion yang mengikuti mode terbaru. Sedangkan konsumsi jasa melalui pemenuhan kebutuhan yang berorientasi kesenangan terhadap tempat hiburan, misalnya, tempat rekreasi atau tujuan dengan lokasi yang prestisius.

Suatu keniscayaan bagi individu untuk menghindar dan membatasi diri dari hasil kemajuan peradaban. Tawaran barang dan jasa yang prestisius setiap detik ditawarkan melalui teknologi informasi yang mudah diakses. Tampilan barang komoditi yang ditawarkan melahirkan sensasi kesenangan tampil dengan "citra" yang mewakili makna simbolik dari sebuah kemewahan. Pada konteks ini, kebutuhan dan keinginan sulit untuk dibedakan.

Talcott Parsons menjelaskan bahwa setiap individu harus memiliki kemampuan beradaptasi sehingga bisa bertahan terhadap lingkungannya. Di sisi lain, individu juga memiliki kemampuan untuk meubah lingkungan sesuai apa yang diharapkan. Sebagaimana dalam skema tindakan Parsons, terdapat empat komponen penting dalam sistem social yakni; actor atau pelaku, tujuan, situasi, dan standar-standar normative yang berlaku dalam masyarakat. Tindakan konsumtif tidak terlepas dari keempat komponen tersebut. Individu sebagai actor atau pelaku memiliki kekuasaan penuh terhadap dirinya untuk mengambil bagian dari lingkungan yang dianggapnya memberikan kontribusi terhadap nilai social dirinya.

Berada dalam komunitas dengan nilai sosial yang berbeda dengan individu atau masyarakat lainnya, menjadi sebuah prestise tersendiri. Realitas tersebut dapat melahirkan status sosial tertentu (status sosial ekonomi), sehingga nilai sosial (status sosial) cenderung lebih penting dibandingkan pemenuhan kebutuhan itu sendiri. Pakaian sebagai kebutuhan dasar untuk melindungi dan menutup diri, sekaligus sebagai pengantar pesan untuk mode atau fashion yang mengepresikan identitas sosial tertentu. Ketika individu berada dalam situasi konsumtif, individu tidak menemukan pelanggaran atau pengabaian terhadap standar-standar normative yang dianggap menciptakan kondisi lingkungan yang tidak stabil. Akibatnya tindakan konsumtif menjadi realitas sosial yang membentuk komunitas 
tertentu dengan mengusung konsep status social ekonomi yang memiliki nilai khusus di tengah masyarakat.

Terkait dengan realitas tersebut, tulisan ini akan mengkaji Konsumtivisme mendorong terciptanya status social ekonomi dengan tinjauan sosiologi dan dirumuskan dalam sub masalah; bagaimana prilaku konsumtif mendorong terbentuknya status social tertentu.

\section{METODE PENELITIAN}

Tinjauan sosiologi terhadap Konsumtivisme dan status sosial ekonomi masyarakat perspektif postmodernisme menggunakan data yang diperoleh dari studi literatur. Literatur yang digunakan berupa buku referensi kajian sosiologi dan sosiologi ekonomi. Selain buku, data diperoleh dari jurnal ilmiah, dan pemberitaan melalui media massa. Data yang diperoleh dipilah berdasarkan fokus kajian dan pembahasan.

\section{PEMBAHASAN}

\section{A. Konsumtivisme}

Konsumtivisme memiliki dua akar kata yaitu "konsumtif" dan "isme". Konsumtif adalah kata sifat yang memiliki kata dasar "consumptus", "consume", konsumsi. Dengan demikian kata konsumtif berarti sifat mengkonsumsi, memakai, menggunakan, menghabiskan sesuatu. Dalam bahasa Inggris kata "konsumtif" digunakan untuk menyatakan penggunaan sesuatu hal dengan berlebih-lebihan, memboroskan, obsesif, dan rakus. Konsumtif, bisa digunakan untuk penggunaan kepada uang, waktu, atau energi dengan berlebihan dan destruktif. Jika demikian maka konsumtivisme adalah sebuah pandangan hidup, gaya hidup, ajaran, sikap atau falsafah hidup yang memakai, mengkonsumsi, menggunakan, menghabiskan sesuatu dengan berlebih-lebihan, memboroskan sesuatu ${ }^{1}$.

Konsumtifiasme merupakan pola-pola konsumsi baru yang merupakan ciri dari satu tahap kehidupan social masyarakat dari modern ke postmodernisme ${ }^{2}$.

${ }^{1}$ https://ahmadrajafi.wordpress.com/2011/01/31/pola-hidup-konsumtif/. Diakses pada tanggal 27 Mei 2020.

2 Postmodernisme merujuk pada satu epos, jangka waktu, zaman, yang mengiringi pemahaman histrois. Lihat, Ritzer, George, Teori Sosial Postmodern (Kreasi Wacana; Yogyakarta, 2010), h. 16. Post modernism lahir untuk mengembalikan kembali "ketidakberartian pribadi" manusia yang terabaikan oleh kekuatan rasional yang mencapai titik tertinggi dalam sebuah proses kehidupan. "Ketidakberartian pribadi" merupakan istilah yang digunakan Giddens akibat perubahan sosial yang demikian pesat. Lihat, Ritzer, George, Teori Sosiologi Modern (Gramedia; Jakarta, 2004), h. 560 . Pandangan Bauman bahwa ciri postmodernitas adalah mengakui 
Fenomena sosial masyarakat menunjukkan tingginya minat masyarakat terhadap mall dibandingkan pasar trandisional, barang bermerek, sarana hiburan, yang pada dasarnya tidak menjadi kebutuhan utama. Mall bukan hanya menyediakan barang tetapi kepesonaan dari arsitektur, dan kenyaman suasana. Sarana hiburan, café telah menjadi representasi dari gaya hidup bukan hanya sebagai tempat makan atau minum ringan tetapi menjadi tempat diskusi semua kalangan, demikian juga sarana yang lain. Keberadaan barang dan jasa tersebut membutuhkan biaya yang tidak sedikit untuk sekedar memperoleh kenyamanan dan kesenangan.

Konsumtivisme atau prilaku konsumtif merupakan kecenderungan atau dorongan untuk mengonsumsi berbagai hal hanya untuk memuaskan keinginan berbelanja, bukan berdasarkan ada tidaknya kebutuhan. ${ }^{3}$ Aprilia dan Hartoyo mendefenisikan prilaku konsumtif sebagai prilaku individu yang dipengaruhi oleh factor-faktor psikologis di dalam kehidupannya yang ditunjukkan mekonsumsi secara berlebihan atau pemborosan atau tidak terencana terhadap jasa dan barang yang tidak diperlukan. ${ }^{4}$ Sedangkan menurut Sumarsono, prilaku konsumtif adalah sebuah prilaku yang tidak lagi didasarkan pada pertimbangan yang rasional, tetapi adanya keinginan yang telah mencapai taraf yang tidak rasional. ${ }^{5}$ Pengertian yang telah dikemukakan menunjukkan bahwa prilaku konsumtif sangat terkait dengan tidak adanya perencanaan atas barang dan jasa dalam pemenuhan kebutuhan, dan pergeseran makna barang dan jasa pada lingkungan individu konsumtif.

Sumarsono mengidentifikasi indicator prilaku konsumtif sebagai berikut ${ }^{6}$;

a. Pembelian produk karena adanya iming-iming hadiah yang akan diperoleh ketika membeli barang tersebut.

b. Ketertarikan karena kemasan yang menarik.

c. Membeli produk untuk menunjang status dan gengsi.

d. Membeli produk atas pertimbangan harga (bukan atas dasar manfaat atau kegunaannya). Konsumen cenderung berperilaku yang ditandakan oleh adanya kehidupan mewah sehingga cenderung menggunakan segala hal yang dianggap paling mewah.

pluralisme, keragaman, serta menentang homogenitas. Jika modernisasi mengusung rasionalitas maka postmodernisme tetap memandang rasionalitas sebagai aspek yang sangat penting, namun tetap ada keseimbangan dengan nilai-nilai agama,moral, dan kearifan lokal. F. Lyotard, melihat kelahiran postmodernisme sebagai bentuk musnahnya paradigma rasionalitas ilmiah dan kembalinya budaya kearifan majemuk dan relativisme pengetahuan. Lihat, Kuper, Adam dan Jessica, The Sosial Science Encyclopedia (PT.RadjaGrafindo Persada; Jakarta, 2000), h. 813.

${ }^{3}$ Mike Rini Sutikno, Fund Planing, (Jakarta: Delta FM, 2009). h. 37.

${ }^{4}$ Aprilia \& Hartoyo, Analisis Sosiologis Perilaku Konsumtif Mahasiswa, Vol. 15, No. 1: 7286 http://publikasi.fisip.unila.ac.id. h. 73, Diakses tanggal 21 Mei 2020

${ }^{5}$ Sumartono, Terperangkap Dalam Iklan, (Bandung: Alfabeta, 2002). h. 117.

${ }^{6}$ Ibid., h. 119. 
e. Membeli produk hanya sekedar menjaga simbol status. Konsumen yang memiliki kemampuan membeli yang tinggi terutama dalam hal penampilan, maka hal tersebut dapat menunjang sifat ekslusif dengan kepemilikan barang yang mahal dan memberi kesan berasal dari kelas sosial yang lebih tinggi. Dengan membeli suatu produk dapat memberikan simbol status agar kelihatan lebih keren dimata orang lain.

f. Memakai produk karena unsur konformitas terhadap model yang mengiklankan. Konsumen cenderung meniru perilaku tokoh yang diidolakannya dalam bentuk menggunakan segala sesuatu yang dapat dipakai tokoh idolanya. Konsumen juga cenderung memakai dan mencoba produk yang ditawarkan bila ia mengidolakan publik figur produk tersebut.

g. Munculnya penilaian bahwa membeli produk dengan harga mahal akan menimbulkan rasa percaya diri yang tinggi. Konsumen sangat terdorong untuk mencoba suatu produk karena mereka percaya apa yang dikatakan oleh iklan yaitu dapat menumbuhkan rasa percaya diri.

h. Mencoba lebih dari dua produk sejenis (merek berbeda). Konsumen akan cenderung menggunakan produk jenis sama dengan merek yang lain dari produk sebelum ia gunakan, meskipun produk tersebut belum habis digunakan.

Indikator prilaku kolektif yang dikemukakan Sumarsono memberikan pemahaman terhadap unsur-unsur yang melingkupi prilaku kolektif, sebagai berikut; 1). Prilaku konsumtif tidak memiliki perencanaan, melampaui batas kebutuhan, dan hanya mengikuti kesenangan. 2). Kecenderungan yang kuat untuk menyamai, menandingi, melebihi tindakan individu lain dengan menampilkan diri secara berbeda.3). Barang dan jasa menjadi simbol status social dan memperoleh pengakuan dari masyarakat di lingkungannya.

\section{B. Status Sosial Ekonomi}

Soerjono Soekanto memberikan pengertian tentang status yakni; a) posisi dalam suatu hierarki. b) suatu wadah bagi hak dan kewajiban. c) aspek status dari peranan. d) prestise yang dikaitkan dengan satu posisi, dan e) jumlah peranan ideal dari seseorang ${ }^{7}$. Dari defenisi tersebut, dapat disimpulkan bahwa status merupakan tempat atau posisi seseorang dalam menjalankan hak dan kewajibannya dalam suatu kelompok sosial. Defenisi tersebut dapat menjadi rujukan bagi pengertian status sosial yang menempatkan status pada pengertian yang lebih luas yakni dalam masyarakat.

${ }^{7}$ Soerjono Soekanto, Sosiologi Suatu Pengantar, (Jakarta: RadjaGrafindo, 2003) h.422. 
Mayor Polak membagi status dalam dua aspek yakni aspek struktural dan aspek fungsional. Pada aspek struktural memiliki sifat hierarkis yang mengandung pengertian adanya perbandingan tinggi dan rendah terhadap status yang lain. Sedangkan aspek fungsional dimaksudkan sebagai peranan sosial (social role) yang berkaitan dengan status tertentu yang dimiliki seseorang ${ }^{8}$.

Status atau kedudukan adalah sebagai tempat atau posisi seseorang dalam suatu kelompok sosial, sehubungan dengan orang lain dalam kelompok tersebut, atau tempat suatu kelompok sehubungan dengan kelompok-kelompok lain di dalam kelompok yang lebih besar lagi. Kedudukan, tempat atau posisi seseorang dalam sebuah kelompok dapat merupakan kedudukan yang bersifat ganda atau memiliki status (kedudukan) dalam masyarakat. Status atau kedudukan yang berhubungan dengan jabatan atau pekerjaan dapat dikategorikan sebagai status yang bersifat obyektif dengan hak dan kewajiban yang terlepas dari individu. Sedangkan pendidikan dan kekayaan dapat dikategorikan sebagai status yang bersifat subyektif atau status yang menunjukkan hasil dari penilaian orang lain.

Status sosial ekonomi secara khusus merupakan posisi yang ditempati individu atau keluarga yang berkenaan dengan standar normatif yang umum berlaku tentang kepemilikan kultural, pendapatan efektif, pemilikan barang dan partisipasi dalam aktifitas kelompok dari komunitasnya. Soekanto mengemukakan faktor yang mempengaruhi status sosial ekonomi yakni; pekerjaan, pendidikan, pendapatan, jumlah tanggungan, pemilikan, dan jenis tempat tinggal.

Sudarsono mengemukakan standar-standar umum sebagai indicator objektif dan subyektif status sosial ekonomi, sebagai berikut;

a. Pendidikan

b. Jenjang jabatan yang menggunakan skor

c. Pendapatan bagi yang bekerja berupa gaji atau upah

d. Pemilikan barang berharga yang langsung dapat dilihat oleh orang lain yang diduga sebagai simbol atau pertanda status sosial yang mendapat pengakuan dari masyarakat atau sekitar lingkungannya.

e. Adanya pengakuan dari masyarakat atau lingkungannya sebagai indicator subyektif ${ }^{9}$.

\section{Konsumtivisme dan Status Sosial Ekonomi}

Pola konsumtif sangat terkait dengan sistem sosial, bagaimana seorang individu atau sekelompok individu mampu beradaptasi dengan lingkungannya. Standar-

8 Abdul Syani, Sosiologi Skematika, Teori dan Terapan (Jakarta: Bumi Aksara, 1992) h. 91.

9 Sudarsono, Pengukuran Status Sosial Ekonomi dan Permasalahannya, (Jurnal Populasi Nomor 2 Tahun 1990). h.23.

22 
standar umum tentang status social yang tinggi, atau penghargaan khusus dari masyarakat merupakan rumusan standar masyarakat itu sendiri. Bagaimana perlakukan terhadap individu atau sekelompok individu karena berbeda dengan yang lain, sebagai dampak dari pelampauan standar-standar umum tersebut.

Penerimaan terhadap makna simbol dari suatu barang dan jasa, juga merupakan hasil konstruksi masyarakat. Bagaimana persepsi masyarakat terhadap individu yang memiliki barang berkelas (berharga tinggi) serta gaya hidup mewah, akan berbanding lurus dengan perlakuan atau tindakan social dari individu atau masyarakat.

Faktor yang medukung prilaku konsumsi dalam masyarakat dijelaskan Lury dalam Mutia sebagai berikut; ${ }^{10}$

a. Peningkatan barang baik dari jumlah maupun jenis barang dalam jumlah besar. Kebutuhan masyarakat yang semakin meningkat mendorong penyediaan barang dan jasa dari berbagai jenis dan variasi barang.

b. Kemudahan akses dalam pertukaran barang sebagai dampak dari interaksi masyarakat yang mengalami peningkatan. Kemajuan teknologi informasi yang memudahkan masyarakat dalam mengakses barang yang diinginkan tanpa harus mengeluarkan biaya yang tinggi karena dapat dilakukan secara online.

c. Pertumbuhan pusat perbelanjaan modern dengan arsitektur yang mewah, café, sarana rekreasi yang memberi kenyamanan bagi pengunjung.

d. Citra yang ditampilkan dalam kemasan barang dan jasa (gaya, desain)

e. Peran media dalam periklanan barang dan jasa. Media menyajikan gambar, pesan, suara yang dapat mensimulus persepsi seseorang terhadap obyek konsumsi tertentu.

f. Penggunaan kartu kredit memudahkan masyarakat untuk berbelanja.

Letche dalam Mutia Hastuti mengulas budaya konsumsi yang dilatarbelakangi oleh munculnya masa kapitalisme. Kapitalisme menurut Karl Marx merupakan cara produksi berdasarkan kepemilikan pribadi sebagai sarana produksi. Tujuan kapitalisme adalah bagaimana memperoleh keuntungan sebesar-besarnya meskipun dengan cara mengeksploitasi pekerja atau buruh. Komoditas sebagai hasil produksi dipandang Marx pada dua aspek yaitu; use value dan exchange value. Use value atau nilai guna tidak dimaknai secara fungsional sebagai kegunaan dalam pemenuhan kebutuhan. Sedangkan exchange value menekankan pada nilai tukar terhadap komoditi tersebut.

10 Mutia Hastiti Parwanti, Masyarakat Konsumeris Menurut Konsep Pemikiran Jean Baudrillard, http://lib.ui.ac.id/file?file=digital/20351974-MK-Mutia\%20Hastiti\%20Pawanti.pdf, diakses tanggal 27 Mei 2020.

23 
Jean Baudrillard, tokoh filsafat postmodernisme melihat bahwa sebuah komoditi bukan hanya memiliki use value dan exchange value, tetapi juga memiliki symbolic value dan sign value. Seseorang tidak hanya mengonsumsi sebuah objek berdasarkan nilai guna tetapi nilai simbolik dan nilai tanda yang bersifat abstrak ${ }^{11}$. Pandangan Baudrillard menunjukkan bahwa perilaku konsumsi yang terjadi tidak hanya dipengaruhi faktor-faktor murni ekonomis serta pilihan rasionalnya, tetapi juga adanya sistem budaya dan persepsi sosial yang mampu mengarahkan pilihan individu terhadap komoditi tertentu.

Nilai simbol pada suatu barang atau jasa merupakan representasi dari makna dibalik barang itu sendiri. Kepemilikan barang bermerk atau fashion yang up to date merupakan represetanse dari kemampuan finansial yang berlebih dari pemilik. Barang yang mewah menandakan barang tersebut mahal dan membutuhkan nilai tukar yang tinggi. Bagi masyarakat kepemilikan tersebut memiliki simbol status social ekonomi.

Pada paradigma postmodernisme, standar-standar umum atau nilai-nilai yang diakui masyarakat tidak terbentuk begitu saja. Standar atau nilai-nilai tersebut melalui proses konstruksi yang melibatkan individu dan masyarakat. Pada satu sisi, individu merumuskan standar atau nilai-nilai sebagai hasil objektifasinya dengan masyarakat, di sisi lain masyarakat mengeksternalisasi nilai tersebut yang sifatnya mengikat individu di dalamnya. Hal ini terkonstruksi, bagaimana sebuah nilai dapat diterima sebagai sebuah realitas, bahwa status sosial ekonomi merupakan hasil dari pola konsumtif atau kepemilikan barang atau jasa. Masyarakat memberikan analisis atas status sosial ekonomi berdasarkan penerimaan masyarakat terhadap standar atau nilai umum, antara lain mencakup gaya hidup (life style) sebagai identitas seseorang.

\section{PENUTUP}

\section{A. Kesimpulan}

Berdasarkan pembahasan diatas maka, disimpulkan sebagai berikut :

1) Konsumsi tidak lagi dilihat dalam perspektif fungsional sebagai kebutuhan yang memiliki nilai guna, dan pertukaran ekonomi. Kemajuan peradaban yang salah satunya ditandai dengan kemajuan teknologi informasi memberi kemudahan dalam mengakses kebutuhan atas barang dan jasa. Di sisi lain, sejumlah faktor memotivasi dan memengaruhi tindakan ekonomi yang melampaui kebutuhan sesungguhnya. Pada konteks ini, use value dan exchange

11 Mutia Hastiti Parwanti, Masyarakat Konsumeris Menurut Konsep Pemikiran Jean Baudrillard, http://lib.ui.ac.id/file?file=digital/20351974-MK-Mutia\%20Hastiti\%20Pawanti.pdf, diakses tanggal 27 Mei 2020.

\section{4}


value bergeser menjadi simbolik use dan sign value. Barang dan jasa adalah symbol dan tanda dengan standar atau nilai-nilai melampaui standar pada umumnya. Kepemilikan merupakan symbol status sosial ekonomi, yang berkonsekeunsi pada perlakukan yang berbeda dari lingkungannya. 


\section{DAFTAR PUSTAKA}

Hartoyo, Aprilia. Analisis Sosiologis Perilaku Konsumtif Mahasiswa. Vol. 15, No. 1: 72-86 http://publikasi.fisip.unila.ac.id.

Kuper, Adam dan Jessica. The Sosial Science Encyclopedia, Jakarta: PT. Radja Grafindo Persada, 2000.

Parwanti, Mutia Hastiti. Masyarakat Konsumeris Menurut Konsep Pemikiran Jean Baudrillard, http://lib.ui.ac.id/file?file=digital/20351974-MKMutia\%20Hastiti\%20Pawanti.pdf, diakses tanggal 27 Mei 2020.

Ritzer, George. Teori Sosial Postmodern, Yogyakarta: Kreasi Wacana, 2010. - Teori Sosiologi Modern, Jakarta: Gramedia, 2004.

Sutikno, Mike Rini. Fund Planing, Jakarta: Delta FM, 2009.

Sumartono. Terperangkap Dalam Iklan, Bandung: Alfabeta, 2002.

Soekanto, Soerjono. Sosiologi Suatu Pengantar, Jakarta: Radja Grafindo Persada, 2003.

Syani, Abdul. Sosiologi Skematika, Teori dan Terapan, Jakarta: Bumi Aksara, 1992.

Sudarsono, Pengukuran Status Sosial Ekonomi dan Permasalahannya, Jurnal Populasi Nomor 2 Tahun 1990.

https://ahmadrajafi.wordpress.com/2011/01/31/pola-hidup-konsumtif/. Diakses tanggal 27 Mei 2020. 